\title{
CONSTRUCTIVE ACCELERATION UNDER GOVERNMENT CONTRACTS
}

\author{
Geoffrey Creyke, JR.* and H. Randall Bixler $\dagger$
}

With ever increasing frequency members of the legal profession are becoming involved in the handling of claims under government contracts at the administrative level, including the various boards of contract appeals, of which there are fourteen at this writing. It is believed that one of the refinements in this specialized area of the law, "constructive acceleration" claims, will be of particular interest, first because of its dissimilarity to anything normally encountered in a general law practice; second, because it is a relatively new concept even within the field of government contracting; and third, because it is becoming a prevalent type of claim particularly under missile site and major defense installation contracts and in other "exotic" areas of public construction work. The Department of Defense, Atomic Energy Commission, National Aeronautics and Space Administration, and other government departments and agencies are annually receiving vast appropriations to be expended through federal contracts, for numerous projects, which due to their urgency and uniqueness are particularly prone to what contractors and contract lawyers have come to know as "acceleration" claims.

I

What Is "Acceleration"?

A. Advancing Time of Performance

The traditional concept of "acceleration" is the mere expediting of the performance of a contract to accomplish a given goal at a time prior to that originally anticipated by the contracting parties. Naturally there have been cases where the government, usually as part of a defense effort, has requested or directed a contractor to perform his work in less time than specified in the contract as awarded. Normally these are treated as routine changes under General Provision Three of Standard Form 23A. However, occasionally they reach the appeal boards.

For example, in Corona Felt Mills, Inc., ${ }^{1}$ a contract was awarded to the appellant to furnish cloth materials for use in the manufacture of military uniforms. The contract specified that the material would be delivered in increments by certain dates and stated a final completion date. Due to the advent of the Korean War, the

*A.B. 1932, LL.B. I935, George Washington University. Vice Chairman, Public Contracts Division, Administrative Law Section, American Bar Association. Partner, Hudson \& Creyke, Attorneys at Law, Washington, D.C. Member of the District of Columbia, Maryland, and United States Supreme Court bars. Lecturer, panelist, and contributor to various symposia and periodicals in the field of public contracts.

†A.B. 1957, Michigan State University; LI.B. I961, George Washington University. Member of the District of Columbia bar. Associate, Hudson \& Creyke, Attorneys at Law, Washington, D. C.

${ }^{1}$ Armed Services Board of Contract Appeals (ASBCA) No. 1007 (1953). 
Air Force desired earlier delivery than it had contracted for and accordingly directed the contractor to expedite his performance. The contracting officer agreed to pay any additional costs so incurred by the contractor, but since the parties disagreed, a board proceeding was necessary as to the amount of the costs to which the appellant was entitled.

A similar set of facts was presented in the Barrister Corporation, where the Armed Services Board of Contract Appeals (ASBCA) held that under such circumstances a contractor was entitled to recover costs incurred in attempting to accelerate or expedite performance even though that attempt was unsuccessful due to excusable delays for which the contractor was entitled to an extension of performance time under a provision of the contract.

On the other hand, in Spera Construction Company, ${ }^{3}$ the contractor was denied additional costs although the contracting officer had requested him to expedite performance, since an applicable appropriation act provided that none of the funds thereunder should be expended for expediting work unless the Secretary of Defense certified that such costs were necessary to protect the national interest. Furthermore numerous government contracts-particularly supply type contracts-provide a sliding scale price adjustment for the delivery of materials at times prior to the maximum dates fixed by the contract schedules.

Generally this type of expediting or acceleration creates relatively few problems in government contracting, as evidenced by the dearth of case law involving such matters. Normally under these circumstances the government agrees, either within the contract or by supplemental agreement, to pay the contractor his reasonable additional costs.

\section{B. Acceleration Caused by Disruption of Progress}

In addition to providing for completion dates, and often for substantial daily liquidated damages, most government contracts and virtually all construction contracts contain a provision (frequently General Condition 05) which requires the contractor, within a reasonable time after commencement of the work, to prepare and submit to the contracting officer, for his approval, a practicable and feasible progress schedule showing the order of the work and the date on which the contractor will commence the several salient features thereof. Such clauses also contain the following or similar language:

The contractor shall furnish sufficient forces, construction plant, and equipment, and shall work such hours, including night shifts, overtime operations, and Sunday and holiday work, as may be necessary to insure the prosecution of the work in accordance with the approved progress schedule. If, in the opinion of the contracting officer, the contractor falls behind the progress schedule, the contractor shall take such steps as may be necessary to improve his progress, and the contracting officer may require him to increase the num-

2 ASBCA No. 1036 (1953).

${ }^{3}$ ASBCA No. 3063, 56-2 BCA ro62. 
ber of shifts, and/or overtime operations, days of work, and/or the amount of construction plant, all without additional cost to the government.

It is clear that in the event the contractor falls behind an approved progress schedule, the contracting officer can require it to re-attain scheduled progress by the various means described in the above contract provision, all without additional cost to the government. ${ }^{4}$

However, all government construction contracts contain another provision, General Provision Five, Termination for Default-Damages for Delay-Time Extensions, which provides:

(c) The right of the contractor to proceed shall not be terminated, as provided in paragraph (a), nor the contractor charged with liquidated or actual damages, as provided in paragraph (b) hereof, because of any delays in the completion of the work due to unforeseeable causes beyond the control and without the fault or negligence of the contractor, including, but not restricted to, acts of God, or of the public enemy, acts of the government, in either its sovereign or contractual capacity, acts of another contractor in the performance of a contract with the government, fires, floods, epidemics, quarantine restrictions, strikes, freight embargoes, and unusually severe weather, or delays of subcontractors or suppliers due to such causes: Provided, that the contractor shall within ten (Io) days from the beginning of any such delay, unless the contracting officer shall grant a further period of time prior to the date of final settlement of the contract, notify the contracting officer in writing of the causes of delay. The contracting officer shall ascertain the facts and the extent of the delay and extend the time for completing the work when in his judgment the findings of fact justify an extension, and his findings of fact thereon shall be final and conclusive on the parties hereto, subject only to appeal as provided in Clause 6 hereof.

Therefore, a contracting officer must grant time extensions for any delays incurred by the contractor not due to the contractor's fault or negligence. Such excusable delays must be manifested on the contractor's progress schedule, if the schedule is to be realistic.

The question posed for our purposes is what are the rights of a contractor where the contracting officer fails to properly and promptly adjust the contract progress schedule for excusable delays, then informs the contractor that it is his (the contracting officer's) opinion that the contractor is behind schedule and directs an increase in the number of shifts worked and/or overtime operations, days of work or the amount of construction plant, as necessary steps to improve that progress? Similarly, what are the rights of a contractor where, after failing to properly extend the contract for excusable delays, the contracting officer insists that the contractor comply with the original completion date as specified in the contract?

In either event, the short answer is that the contractor is entitled to an equitable

\footnotetext{
'Henry J. Kaiser Co., et al., U.S. Army Corps of Engineers Board of Contract Appeals (Eng. BCA) No. $1794\left(\mathrm{rg62}^{2}\right)$. It is noted that the predecessor to this board is cited Eng. C \& A Bd.

- General Services Administration, Standard Form 23A, Construction Contract.
} 
adjustment both in the contract price and in the time for performance thereof under the changes article of the standard form government contract.

The standard form changes article (General Provision Three) ${ }^{6}$ provides in part:

The contracting officer may at any time, by a written order, and without notice to the sureties, make changes in the drawings and/or specifications of this contract and within the general scope thereof. If such changes cause an increase or decrease in the amount due under this contract, or in the time required for its performance, an equitable adjustment shall be made and the contract shall be modified in writing accordingly.

Innumerable cases interpreting this contract provision hold that no written directive (formal change order) is necessary to enable a contractor to obtain relief under the changes article. These cases recognize the doctrine of constructive change orders, i.e., situations where the contracting officer should have issued a written directive changing the plans or specifications but failed to do so. ${ }^{7}$ Thus, where a contracting officer has issued an acceleration directive on the grounds that the contractor is behind schedule, although in fact the contractor is on a properly adjusted progress schedule for excusable delays, there is a constructive change order.

In cases where the contracting officer has issued an acceleration directive on the grounds that the contractor is behind schedule, although in fact the contractor is on a properly adjusted progress schedule, it has been held that the acceleration directive constitutes the written change order contemplated by General Provision Three of the contract.

Before entering upon a discussion of the cases establishing the above doctrines, it should be noted that there is an early Corps of Engineers Board case holding that the contracting officer need have only a reasonable belief that a contractor is behind schedule to justify an acceleration directive at no additional cost to the government. In Intrusion Prepakt, Inc. ${ }^{8}$ it was said:

If the contracting officer had reasonable ground for his belief that the appellant had fallen behind his progress schedule, then the Government would not be answerable for the increased costs attributable to additional shifts of work and overtime wages, etc.

However, no other cases have been discovered where this theory was again applied by this or any of the other boards. From a study of the cases it is quite clear that the rule is as stated in Donald $M$. Drake Company, ${ }^{2}$ concerning a change order for acceleration: "The government must not only be reasonable, it must be right to escape the consequences of a change order."

The doctrine of recourse from unwarranted acceleration becomes quite clear through a reading of the recent applicable cases. In Farnsworth \& Chambers Company, ${ }^{10}$ the contractor was to build a part of the Air Force Academy academic

${ }^{\circ}$ Ibid.

"Industrial Construction Corp., National Aeronautics and Space Administration Board of Contract Appeals (NASA) No. 59-I, 6r-2 BCA 1062.

${ }^{8}$ Eng. C \& A Bd. No. 596 (1955).

${ }^{\circ}$ Eng. BCA No. 1634 (1960).

${ }^{20}$ ASBCA No. 4945 et al., 59-2 BCA 2433. (Emphasis added.) 
complex on or before July 29 , I958. The completion date was of extreme importance to the government in its effort to prepare the complex for the first academic year at the new location. However, during construction the contractor encountered certain delays, some caused by a prior government contractor who had been delayed himself during the erection of the structural steel for some of the buildings upon which the appellant-contractor was to do work. These delays made it virtually impossible for the contractor to construct the complex on schedule. The Armed Services Board of Contract Appeals found that the contractor was entitled to a I73 day time extension for the steel erection delays under General Provision Five of its contract. Notwithstanding the delays, the government had insisted upon completion of the contract within the original performance schedule and had, in fact, directed the contractor to accelerate his performance on the alleged ground that it was behind schedule. The Board said:

A somewhat similar problem was before us in the appeal of Standard Store Equipment Co., ASBCA No. 4348, 28 August 1958 , 58-2 BCA sec. 1902. We have stated,

"The government's failure to make the building available to the contractor until 26 December was an excusable cause of delay under para. (b) of the 'Default' clause entitling the contractor to an extension of the completion date to at least two and one half or three weeks after 26 December. The direction to complete the contract by 4 January was a direction to accelerate performance and complete at an earlier date than was required by the contract.

"An order to accelerate completion has been held to be compensable under the 'Changes' clause. In Samuels and Gundling, BCA No. II47 (1949), a predecessor of this Board held:.. . We have reached the conclusion that by reason of delay set forth by the appellant, it should have been granted an additional 29 days beyond the time allowed by the contracting officer ....?

"Refusal by the contracting officer to grant these extensions and his order to compensate for the delays by accelerating expedition of the work were, in our opinion, changes to the specifications of the contract within the meaning of art. 3 (Changes) .... Therefore, if the appellant can show with reasonable certainty and definiteness that it was put to increased costs by the ordered acceleration, and the amount thereof, it should receive an equitable adjustment therefore in conformity with the facts."

We find the situations comparable and conclude that the act of the government requiring the appellant to complete the buildings sooner than would have been the contract completion date had the time of performance been extended for excusable delays, was a change for which appellant was entitled to an equitable adjustment in contract price.

In Conn Structors, ${ }^{11}$ the contracting officer had directed the contractor to accelerate its performance and the issue before the Board was whether or not the contractor was on schedule at the time of that order. The Board found that the appellant was entitled to an eighty-day extension of time due to a steel strike in addition to certain other extensions previously granted by the contracting officer. The Board said:

${ }^{11}$ ABSCA No. 5195 et al., 60-I BCA 2627. (Emphasis added.) 
We consider first the issue of whether appellant was on schedule on 24 March 1953. If it was not, pursuant to the provisions of $\mathrm{GC}_{-5}$, quoted above, the government was entitled to direct acceleration until actual progress equaled that designated on a current schedule progress chart. If it was, the order directing acceleration was a change for which appellant would be entitled to ... adjustment.

Again, in Hagstrom Construction Company, ${ }^{12}$ the Armed Services Board said:

The right of the government to demand acceleration, i.e., increase the number of shifts and/or overtime operations, days of work and/or amount of construction plant, without additional cost to the government, may be exercised only if appellant had fallen behind the progress schedule. The progress schedule to be used in determining whether appellant had become delinquent must be a current schedule, a schedule which reflects credit for extensions and excusable delays encountered by appellant. The contract pro. vided for the granting of extensions of time for excusable delays which must be reflected in the progress schedule and must be considered in determining status of performance by appellant. Extensions would, of course, postpone the completion date of the individual phases of the project, as well as the date the entire project was to be finished.

In the instant appeal, the contracting officer, in determining delinquency on the part of the appellant, measured attained progress against the original progress schedule. If excusable delays, for which time extensions are authorized by the contract, were encountered after the original progress schedule was prepared and submitted to the government, comparing actual progress with a schedule not reflecting credit for such delays is error. ...

The Board continued, finding that there were excusable delays, and held:

Since several directives to add workmen and to work overtime are involved, each complied with by appellant, causing additional costs, when it was not, in fact, behind the CURRENT progress schedule-one appropriately modified, granting credit for the delay in receiving steel at the job site-was a change for which appellant is entitled to an equitable adjustment.

\section{Materials at Site as Element of Progress}

The various causes for excusable delay entitling a contractor to a time extension and to adjustment of his progress schedule are quite numerous and beyond the scope of this article. In addition to controversies over the right to time extensions, there is another area of dispute concerning the adjustment of a progress schedule which often arises in acceleration claims. Most government construction contracts provide that in addition to progress payments for the work in place the government may also make progress payments representing the cost of materials procured for the project and delivered to the job site but not yet incorporated into the work. Ordinarily, contracting agencies pay from fifty per cent to ninety per cent of these costs. The question arises, however, as to whether these "materials job site" must be

${ }^{22}$ ASBCA No. 5698, 6r-I BCA 3090. (Emphasis added.) Accord: J. W. Bateson Co., Inc., ASBCA No. 6069, x962 BCA 3529; Intrusion Prepakt, Inc., Eng. C \& A Bd. No. 596 (1959); Satchwcll Electric Construction Co., Inc., Eng. C \& A Bd. No. 1256 (1957); Standard Store Equipment Co., Inc., ASBCA No. 4348, 58-2 BCA r902; Mechanical Utilities Inc., ASBCA No. 7466, I962 BCA 3556; Charles Harris Co., Eng. BCA No. I494 et al. (1959). 
considered as contractor progress for purposes of a properly adjusted progress schedule. Although the only reported cases discussing this subject make it clear that the contractor is entitled to progress on this account, many government representatives continue to take a contrary position, particularly in field level negotiations. In Conn Structors, ${ }^{13}$ the Armed Services Board of Contract Appeals said:

Another disputed area involved in this phase of the appeal concerns the actual progress attained by appellant on 24 March r953. The government takes the position that progress attained should be measured in terms of "work in place," that is, work completed and incorporated in the final structure. The appellant contends that progress should be computed to reflect work in place, together with credit for the value of all necessary materials acquired and stored at the construction site, even though not incorporated in the final structure, and for the value of all the preparatory work, which included contractor's plant and equipment at the site.

We are of the opinion that preparatory work and purchased materials stored at the construction site must be considered in determining attained progress. To say that the acquisition of supplies, which included materials prefabricated specially for this project, and the delivery of such materials, some of which required very little work on the part of the appellant, to be incorporated in the final project, is not progress is unrealistic. Article $\mathrm{GC}_{-5}$, quoted above, stated that ". . . the order in which the contractor proposes to carry on the work, the date on which he will start the several salient features (including procurement of materials, plant, and equipment) and the contemplated basis for completing same. ..."

Acquisition of materials and preparatory work were to be included in the preparation of a progress schedule chart. Attained progress, which is to be compared to scheduled progress for the purpose of determining whether the appellant was on or behind schedule, should also include credit for procured materials and preparatory work. At least two government expert witnesses offered testimony confirming this conclusion. We believe that acquisition of materials and preparatory work were included in the schedule progress charts. To compare attained progress, crediting work in place, with a schedule progress chart which includes preparatory work and stored materials is error.

The Board went on to hold that the appellant should be granted progress for "materials job site" to the extent of "at least twenty-five per cent of acquired materials."

\section{Dilatoriness by the Contracting Officer in Granting Time Extension}

Some government contracting officers take the unfortunate position that extensions of time for excusable delays, as well as extensions of time to perform changed work, should not be granted as they occur, hut should be held in abeyance and determined at the end of the project. Regrettably, although government contracts establish ominous deadlines for contractors, this is not reciprocal; in this and other

\footnotetext{
${ }^{13}$ Supra note II. (Emphasis added.) Accord: S \& E Contractors, Inc., Atomic Energy Commission
} (AEC), C \& A No. I6r et al. (1963). 
areas the contracts do not require a determination within any set period of time by the contracting officer. Such a procedure places a contractor in the difficult position of having to perform work with no fixed time schedule and thus without definite knowledge of where he stands in relation to the government's right to terminate him for default or to assess him for liquidated or actual damages. There is a natural tendency for contractors to increase the pace of their performance under such circumstances.

It appears clear, if inequitable, however, that if the government does not direct the contractor to accelerate, insist upon completion of the contract within the original completion date, or threaten to terminate or take some overt action, there is no compensable acceleration change.

In T. C. Bateson Construction Company, ${ }^{14}$ it was said,

The record in this case does not support the appellant in any claim based on acceleration due to the failure of the Contracting Officer to grant an acceptable extension of time for performance. There was never an insistence on complying with an original completion date such as there was in appeals of Farnsworth and Chambers Company, ASBCA Nos. 4945, 4978 and 5129, 59-2 BCA 2433. Here the time remained in negotiation and could not be determined until after the time (the winter of 1957 -1958) during which it is now claimed the work was accelerated.

In Lewis Construction Company, ${ }^{15}$ the contractor claimed an acceleration change on the basis that he accelerated his performance due to a fear that the contracting officer would terminate him for default. On the facts, the Board found that there was no threat of termination and,

Moreover, assuming the allegation to be true, appellant's claim must still fail. Appellant's fear of default termination is without foundation and self-imposed. Since there was no threat of termination made by the government, and since the government was without authority to terminate if the delays were excusable, appellant's action, in accelerating, if done in fear of termination, must have been the result of its erroneous belief that the contract could have been terminated. Costs incurred as a result of an erroneous interpretation of contract provisions must be charged to the party who erroneously interprets the contract.

However, the Lewis case at least implies that, if there had been a threat to terminate the contractor for default, during a period when it was entitled to a time extension for excusable delays, and if, as a proximate result of that threat, the contractor accelerated its performance, such action would be compensable under the changes article.

In Intrusion Prepakt, Inc., ${ }^{16}$

Statements were made to the appellant by representatives of the contracting officer on 30 January and 4 February 1953 to the effect that the appellant was not prosecuting the work with such diligence as would insure its completion by 2 March 1953 and that the job

${ }_{11}$ ASBCA No. 6128, 60-2 BCA 2757. Accord: Power Equipment Co., ASBCA 5904, 1964 BCA -

${ }^{15}$ ASBCA No. 5509, 60-2 BCA 2732.

${ }^{16}$ Sttpra note 8. 
would be completed by that date even if it were necessary for the government to terminate the contractor's right to proceed. Upon that premise the appellant was "urged" to work on week ends and otherwise during hours requiring payment of premium wages. Such action by representatives of the contracting officer is tantamount to and in legal effect constitutes an order to improve or accelerate progress of the work within the purview of paragraph $\mathrm{GC}_{-5}$ of the specifications, quoted in finding No. I3.

As a corollary, where a contracting officer unjustifiably orders a contractor to accelerate performance, and the contractor fails or refuses to comply with that directive, the contractor is not entitled to an equitable adjustment under the changes article, or, in any event, there can be no recovery since there is no increase to the cost of performance. ${ }^{17}$

Although there are no reported cases directly in point, a contractor apparently could be terminated for refusal to comply with an acceleration directive, even though he was entitled to adequate time extensions, since the changes article (General Provision Three) requires a continuation of performance subject to such relief as may be obtained via the disputes procedure of General Provision Six.

Supply contractors and others on cost-type contracts should be aware of any "limitation of cost" article in their contract if they are subjected to an unjustified acceleration directive. It is clear that, although they might ordinarily be entitled to an equitable adjustment under the theories discussed above, the limitation of cost provision, which prescribes the maximum amount expendable for the work, takes precedence and no recovery can be allowed. ${ }^{18}$ The same rule would seem to apply to Capehart Housing construction contracts, where there is a statutory limitation upon the amount that can be expended on each such contract.

\section{II}

\section{RightS OF SUBCONTRACTORS}

It is beyond the scope of this article to discuss either the general rights of subcontractors to administrative equitable adjustments from the government through their prime contractor or prime-sub relationships. We will mention, however, that the so-called Severin doctrine ${ }^{19}$ restricts a subcontractor's recovery in some instances. For our purposes it will suffice to state that, as a general rule, a prime contractor cannot recover from the government on behalf of a subcontractor unless the prime contractor is liable to the subcontractor. However, where the Severin doctrine does not bar a subcontractor's claim generally, a subcontractor is entitled, through its prime contractor, to an equitable adjustment for an unjustified acceleration. ${ }^{20}$ The rule is applicable even though the subcontract contains a provision that

\footnotetext{
${ }^{17}$ Montgomery-Macri Co., et al., Interior Board of Contract Appeals (IBCA) No. 59 (rg63).

${ }^{18}$ Spencer-Stafford Loadcraft, Inc., ASBCA No. 6592 et al., r962 BCA 3315.

${ }^{10}$ Severin v. The United States, 99 Ct. Cl. 435 (x943), cert. denied, 322 U.S. 733 (1943).

${ }^{20}$ Farnsworth and Chambers Co., ASBCA No. 5988, 60-2 BCA 2733; J. W. Bateson Co., ASBCA No. 6069 , 1962 BCA 3529.
} 
a subcontractor cannot recover delay costs, since acceleration is the exact opposite of a delay claim. ${ }^{21}$

A subcontractor cannot recover acceleration costs from the government through the prime contractor where the prime contractor has agreed to accelerate its performance at no additional cost to the government. ${ }^{22}$

A discussion of subcontractor acceleration claims raises one interesting question or dilemma. The Armed Services Board of Contract Appeals follows the rule stated in the appeal of John Andresen \& Company, ${ }^{23}$ wherein a prime contractor was held entitled to an extension of time for excusable delays although the delays stemmed from the fault or negligence of the prime contractor's subcontractors or vendors. ${ }^{24}$ It thus appears that before that Board a prime contractor could use subcontractor caused delays to prove it was on schedule at the time of an acceleration directive, although it could not claim the costs associated with the subcontractor's accelerated effort since it is not liable to the subcontractor.

On the other hand, the Interior Board of Contract Appeals and the Comptroller General of the United States have refused to follow the Andresen doctrine and do not allow time extensions for delays incurred due to the fault or negligence of a subcontractor. ${ }^{25}$ Before those tribunals, it would appear that a prime contractor could not recover its own acceleration costs where proof that it was on schedule was dependent on subcontractor caused delays.

Accordingly, in most acceleration situations, it is advisable for the parties to analyze not only the general progress schedule but also the progress schedule for each separable portion of that work-electrical, mechanical, and so forth-then undertake to evaluate their position in light of the forum which will have cognizance of the case. ${ }^{28}$

\section{III}

\section{The Equitable Adjustment}

Any itemization or set of guidelines as to quantum in an equitable adjustment under the changes article to compensate the contractor for acceleration is difficult to compile from the reported cases. Much of the problem stems from the fact that most of the successful acceleration appeals were remanded to a contracting officer for the negotiation of price with the contractor. ${ }^{27}$ In addition, there are cases which

${ }^{21}$ Farnsworth and Chambers Co., supra note 20.

${ }^{22}$ Hyde Construction Co., et al., Eng. BCA No. I873 (I962).

23 ASBCA No. 633.

${ }^{24}$ Huntington Seating Co., ASBCA No. 7784 , x962 BCA 3396.

${ }^{25}$ Eagle Construction Corp., IBCA No. 230, 60-2 BCA 2703; Comp. Gen. Dec. No. B-140166, 39 Decs. Conr. Gen. 343 (I959).

${ }^{20}$ It is noted that the more recent editions of the standard form government contracts avoid the Andresen problem by expressly providing for time extensions for subcontractor delays only wherc those delays were without the fault or negligence of the subcontractor.

${ }^{27}$ Farnsworth and Chambers Co., ASBCA No. 4945 et al., 59-2 BCA 2433; Conn Structors, ASBCA No. 5195 et al., 60-r BCA 2627 . 
employ the so-called total cost type settlement ${ }^{28}$ which obviates the necessity for ascertaining costs on an item by item basis. ${ }^{29}$

Those acceleration costs clearly recoverable and specified in the existing decisions are the "premium" costs incurred by a contractor in obtaining materials via expedited purchase orders, transportation by air instead of truck or rail, and labor for overtime, extra-shift, weekend and holiday work. Obviously, neither the anticipated material and transportation costs nor the "straight-time" labor costs, regardless of when they were incurred, are compensable, since all such costs were included in the contractor's bid price. The cases actually deciding or discussing equitable adjustments under an acceleration change order clearly allow premium labor costs, ${ }^{30}$ and premium material costs. ${ }^{31}$ Logic, if not direct precedent, dictates that a contractor should recover any other direct costs which were increased as a proximate cause of an acceleration directive, including premium transportation, and so forth. ${ }^{\mathbf{3 2}}$

The contractor is also entitled to recover the applicable overhead and a fair profit on the costs expended due to the acceleration directive. In Conn Structors ${ }^{33}$ it was said:

The appellant is entitled to an equitable adjustment compensating it for the additional costs incurred in accelerating the work done under contract No. I73. It should include costs expended to the extent that they are not unreasonable, applicable overhead, and a fair profit.

And, where a prime contractor successfully prosecutes an acceleration claim on behalf of its subcontractor, the prime contractor is entitled to its profit and bond costs on the subcontractor's equitable adjustment. ${ }^{34}$

Of course, as in any equitable adjustment under the changes article, the contractor is entitled to recover other costs incident to its acceleration claim but not peculiar to acceleration, such as the cost of preparing and presenting the claim to the contracting officer. ${ }^{35}$

\footnotetext{
${ }^{28}$ Discussed in detail, infra at $153-58$. 2817.

${ }^{30}$ Farnsworth and Chambers Co., supra note 27; Ensign-Bickford Co., ASBCA No. 6214, 60-2 BCA

${ }^{30} \mathrm{~J}$. W. Bateson Co., ASBCA No. 6069, I962 BCA 3529; Intrusion Prepakt, Inc., Eng. C \& A Bd. No. 596 (I955).

${ }^{32}$ Satchwell Electric Construction Co., Eng. C \& A Bd. No. I256 (I957); Ensign-Bickford Co., supro note 29.

${ }^{32}$ See Sol Rrbakoff, Equitable Adjustments Under Governasent Conmracts 35 (Government Contracts Monograph No. 3, I96I).

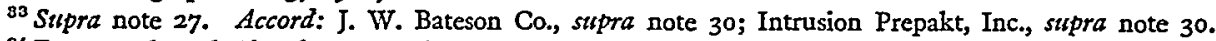

${ }^{34}$ Farnsworth and Chambers Co., ASBCA No. 7130, I962 BCA 3499; J. W. Bateson Co., supra note 30.

${ }^{85}$ Lake Union Drydock Co., ASBCA No. 3073, 59-I BCA 2229; however, see Power Equipment Corp., ASBCA 5904, $\mathrm{rg}_{4} \mathrm{BCA}$-, decided just as this article went to press, which appears to overrule Lake Union on the question of the costs of preparing and presenting claims to the contracting officer.
} 
IV

\section{IMPACT CosTs}

Other costs incurred and claimed by contractors as part of acceleration equitable adjustments are less tangible than the costs previously discussed. Under accelerated conditions with an additional labor force working extra shifts and perhaps weekends and holidays for an extended period, a contractor experiences unusual and intangible added costs. Because his work program has been compressed, a contractor often finds his planned sequence of operation has been severely disrupted.

For example, where the contract calls for the construction of several similar items, or where the contractor plans to repeat an operation a number of times, he can, for estimating purposes, plan on an increasing efficiency by virtue of the normal learning curve as he progresses from the first to the last item. However, where the job is accelerated the normal schedule is so disrupted that employees not only do not become more efficient, but instead they lose a great deal of their normal efficiency. The men who developed the experience may not be performing the next similar increment.

The contractor may also experience what is known as "occupational saturation" or "trade congestion" in the acceleration situation. For example, he may find that his mechanical and electrical contractors as well as his own employees are forced to work in a given area at the same time where, under the original plan of operation, these groups would have performed their work sequentially.

Each of these factors is really a cause resulting in a type of labor inefficiency. In addition it is universally recognized that a contractor can expect labor inefficiency from working employees overtime for extended periods of time. And in the rapid effort to increase his labor force and construction or manufacturing plant a contractor cannot expect to obtain the most, or even normally, efficient additional men or equipment. These cost imponderables cannot be isolated in the accounting records of a contractor, as are the costs of premium labor and materials, and the like. Although these costs actually reflect various types of labor inefficiency they are often referred to as impact costs-that is, the impact of an acceleration directive on the general work of the contractor.

It should be noted also that the normal changes and other problems which ordinarily arise in construction work become more difficult under accelerated conditions. Very often accelerated contracts involve work which, due to its urgency and uniqueness, requires innumerable changes to keep pace with the rapid development of space and defense technology. No one doubts the necessity of making multiple changes in such an atmosphere; but some do not appear to realize the magnitude of difficulties and the ensuing increase in cost experienced by contractors under such circumstances.

In Intrusion Prepakt, Inc., ${ }^{36}$ the Board stated:

${ }^{36}$ Stspra note 30. (Emphasis added.) 
The order to accelerate progress so as to complete the work on or before 2 March should not have been given without an appropriate equitable adjustment in contract price. In compliance with such orders, the appellant incurred premium wages. The premium portion of such wages, taxes thereon, reasonable overhead and profit should have been allowed and now may be allowed in consideration for the relinquishment by the appellant of its right to an extension of four days in the performance period. No additional allowance properly may be made for completing the job ahead of schedule, as no order for such completion can be found or implied from the Government's actions. Furthermore, any further allowances would amount to a duplication of payment. The only allowable element of cost involved in either claim is the premium portion of overtime wages with appurtenant taxes, overhead and profit. Such imponderables, such as "slowdowns" while laborers are working on premium wages, frustration, etc., are too remote for consideration.

The Board cited no case law in support of this position, and as stated, it is believed that this decision has been substantially overruled. Probably it was based upon not only the general law holding that remote or consequential damages are not recoverable, but also on the case of United States $v$. Rice, ${ }^{37}$ which held in effect that since the government "buys the right to make changes" in the drawings and specifications, a contractor cannot recover-either administratively or by a breach of contract action-any costs or damages not flowing directly from that change order. In the Rice case, the Supreme Court was specifically considering the costs to unchanged work which were increased by a change order-i.e., delay-type costs. The Rice defense is often heard by contractors and their attorneys in negotiations with the government on impact-type claims. There is a serious question as to the applicability today of the Rice doctrine to government contracts, in the light of its harshness, its conflict with suspension of work clauses and the acknowledged fact that in practice the average contractor is unaware of it and has no contingency allowance for it in his bid. $^{38}$

In any event, it is submitted that the Rice defense is completely inapplicable to impact costs in acceleration claims, whatever its applicability may be to impact claims arising in non-acceleration situations. In his article, Equitable Adjustments Under Government Contracts, Sol Ribakoff, former Chief Counsel of the Corps of Engineers Ballistic Missile Construction Office, ${ }^{39}$ said,

Our analysis of the costs claimed (under the accelerated ICBM program) led us to conclude that, in large part, the costs could be attributed to the accelerated effort required of the contractors by the government. In this respect, the use of the word "impact" was unfortunate because it seemed to connote consequential rather than direct costs. However, we perceived no inhibition against payment of costs attributable to premium labor, disruption of schedules or premium prices for raw materiảls, use of air-lift rather than conventional modes of transportation, and, after some analysis, the loss of efficiency due to long hours of work, cramped working conditions and interference by the trades.

${ }^{87}$ II7 U.S. 6I (T942).

${ }^{88}$ Shedd, Rice Doctrine and the Ripple Effects of Changes, 32 GEo. WASH. L. Rev. 62 (1963). Mr. Shedd is a member of the Armed Services Board of Contract Appeals.

${ }^{80}$ RiBakofF, op. cit. sipra note 32 , at 36 . 
The logic of Mr. Ribakoff's statement is manifest. Certainly, the types of labor inefficiencies that are, in the aggregate, referred to as impact are the direct consequence of an acceleration directive under the commonly accepted legal standard followed by the courts ever since Hadley v. Baxendale..$^{40}$

The only other acceleration case that has been discovered which discussed loss of efficiency as a specific cost item also found against the contractor, but not on the ground that the labor inefficiencies were consequential damages and thus too remote for recovery. The following quotation from J.W. Bateson Company, ${ }^{41}$ is interesting for its recognition of another often stated government defense to impact costs under acceleration claims:

The claim for the cost of acceleration is presented on appellant's own behalf and on behalf of a number of subcontractors. No demand is made for the salaries of the additional workmen hired as a result of the acceleration. Appellant does claim the cost of all premium pay for overtime from the first acceleration order to substantial completion of the work. Its president testified that, in the experience of his company, overtime hours seldom accomplish any additional productive work. They work overtime voluntarily only when the added pay therefor is necessary to attract sufficient workmen. He stated that the working of overtime hours produced the loss of efficiency through fatigue and also a volitional tendency to slow down on the part of the men. Appellant claims for this loss of efficiency $25 \%$ of the premium wages paid and $10 \%$ of the gross payroll. To this is added $x 1 \%$ for taxes and insurance, $10 \%$ for overhead and $10 \%$ for profit. Claims similarly computed are presented for subcontractors. To the subcontractor's claims, appellant adds $7 \%$ for its profit and bond costs to the total claim.

-...

There are many factors to be considered in arriving at the amount of this equitable adjustment, a number of them intangibles. While appellant was not behind schedule when accelerated, the rate of progress indicated that it probably would have become so. $\mathrm{Ob}$ viously increases in the work force and some overtime would have been necessary for timely completion whether ordered by the government or not. Appellant's subcontractors failed to secure timely delivery of some equipment, making overtime necessary in its installation. There is doubt, however, as to whether the indiscriminate use of overtime accomplishes any significant amount of productive work. At the same time, there were further excusable delays during the acceleration period. Some of these resulted from changing project managers at a critical point, but the extent of delay is impossible to determine. There is a question, but no proof, of whether time extensions were granted for all other excusable delays. Appellant fell slightly behind the extended performance curve during the accelerated period, but substantial completion was ahead of schedule. To further complicate the matter, there remained a substantial amount of "punch list" work to be completed.

In addition to premium wages paid by itself and its subcontractors, appellant requests reimbursement for loss of efficiency. We are persuaded that there is a loss of efficiency attendant upon extended work. The extent thereof will vary dependent upon the daily hours and number of days per week added to the regular schedule. The percentages claimed by the appellant cannot be supported by the record.

${ }^{10} 9$ Exch. 34r, 156 Eng. Rep. I45 (Ex. 1854).

"Supra note 30 . 
We are persuaded from the testimony in evidence as to actual progress that the costs due to loss of efficiency are generally proportioned to the costs from normal overtime work necessary for timely completion, and thus are off-setting. We will base the equitable adjustment allowed on the costs of premium wages with reasonable allowances for overhead and profit.

It is notable that the Armed Services Board in the Bateson case, avoided the problem of the Andresen doctrine, ${ }^{42}$ although it was apparently presented to them rather directly. As the Board stated, "Appellant's subcontractors failed to secure timely delivery of some equipment, making overtime necessary in its installation." More important, however, is the suggestion that the contractor's own inefficiencies offset any additional inefficiency costs incurred by the contractor on account of the acceleration. In addition, the Board seems to hold that since. in normal construction contracts some overtime work can reasonably be anticipated, associated costs should also effect an offset to any claimed acceleration inefficiencies. First, it must be noted that the Board seemed to be considering only that loss of efficiency attributable to working laborers long hours due to the acceleration; it did not specify consideration of such other impact costs as disruption of progress sequences and occupational saturation.

Of course, contractors do in fact recognize that their labor on any given project will not be 100 per cent efficient. Accordingly, there is an allowance for this factor inherent in their bid estimates, since the estimating handbooks used by contractors take this factor into consideration. ${ }^{43}$ It is also true that on some projects contractors do expect overtime work in some portions of the project. This is also provided for in the contractor's estimate. Therefore, these costs can be isolated and compared with the costs claimed for loss of efficiency due to acceleration. However, in the Bateson case the contractor was unable to prove to the Board's satisfaction that the costs attributable to a loss of efficiency were caused only by acceleration. This is a universal problem of contractors in proving their acceleration claims. Even under modern cost accounting methods, it is impossible to isolate and thus enable a contractor to prove, the additional costs incurred by it due to loss of labor efficiency of the various types caused by the impact of an acceleration directive. To the knowledge of the authors, no specific studies have been made by management analysts or others in an effort to determine percentage factors for labor inefficiency under accelerated contracts. In any event, such a factor would necessarily be an arbitrary one as actual costs of impact vary considerably with the particular circumstances of each contract.

Later in this article the authors will set forth their contention that frequently the only practical, fair, and equitable means of compensating a contractor for an unjustified acceleration directive is by the total cost method of settlement, which basically is an adjustment based on the difference between the bid price and the actual costs of performing the work under accelerated conditions. However, for

${ }^{43}$ Supra at p. ${ }_{4} 6$.

${ }^{13}$ Louis Dallavia, Estmating General Construction Costs 5-i6 (2d ed. i957). 
immediate purposes, the Bateson case is cited simply as representing recognition by the Armed Services Board that labor inefficiency is encountered under an accelerated program.

Other cases hold that other types of impact costs are recoverable. The case of Northeastern Engineering, Inc.44 allowed the appellant an equitable adjustment for "increased costs of performance caused by the disruption of its production. ..." Similarly, in Ivey Bros. Const. Company, ${ }^{45}$ it was said,

The government's last contention is that the changes article affords no remedy for incidental, indirect, and consequential damages in the cost of work not changed. We do not believe this defense is applicable for the first three items of appellant's claim. As for the first two of these items, it is alleged that the change required ... extra handling of materials and equipment and presented further physical obstruction to the work. If true, these would be costs flowing directly and not consequentially from the change. The same would also hold true of the third claim for the purchase and construction of additional forms, redesigning forms and placing them out of planned sequence. These costs would be the direct result of the work, not a consequence of delay to work not changed.

The case of Jacobson Construction Company ${ }^{46}$ allowed recovery under the suspension of work article for labor inefficiencies caused by excessive jet airplane noises near the site of the contractor's work.

The recent case of Tenney Engineering, Inc. ${ }^{47}$ did not concern an acceleration directive but did give serious attention to the appellant's impact costs. The case is also precedent for the authors' contention that total cost settlements are allowable, and even necessary, in impact situations:

The nature of the changes is such as to make it appropriate to consider their overall cost effect. Appellant was an experienced and competent contractor and a specialist in the design and construction of environmental test facilities, and there is no suggestion that the original contract price was not reasonable and realistic for the work contemplated. Yet, the actual cost of performance was nearly three times the target price, and the contractor suffered a loss on the contract of more than half a million dollars after price redetermination and after price adjustment for changes allowed by the contracting officer. There is no suggestion that appellant did not perform with a reasonable degree of efficiency, ingenuity, and economy. The record indicates that some of appellant's increased costs resulted from unexpected difficulties in meeting contract requirements, as distinguished from changes imposed on the contractor by the government, but it is obvious that the changes in design imposed on the contractor by the government contributed largely to the increased costs.

It would be highly improper to base the price adjustment for changes on the difference between the contract price and the total costs of performance, and ordinarily total costs of performance are irrelevant to price adjustments for changes. However, in the situation here presented where it is known that the changes imposed by the government had

44 ASBCA No. 5732, 6I-I BCA 3026.

45 Eng. BCA I764 (1960).

${ }^{16}$ Eng. C \& A Bd. No. I55I (I96I).

${ }^{47}$ ASBCA No. 7352, I962 BCA 347 I. 
a far-reaching effect on the overall costs of performance, but it is impossible to make an accurate assignment of costs to specific changes, and where determination of the amount of price adjustment for changes must of necessity depend to an unusual extent on judgment without the aid of accurate cost data, we believe that consideration of the overall costs would give us a better perspective of the changes.

\section{V}

\section{Total Cost Method of Equitable Adjustment}

Most of the acceleration cases involve a determination by the appropriate contract appeal board of whether the government has incurred liability by virtue of an acceleration directive. Where the appellant prevails, the boards then frequently follow a procedure of remanding their determination to the contracting officer to negotiate an equitable adjustment. Of course, it is impossible to tell on what basis a negotiated equitable adjustment was arrived at between parties. We do know from the Comptroller General of the United States ${ }^{48}$ that the total cost basis of settlement was used by the Army Corps of Engineers (CEBMCO) to settle the acceleration claims of most of their missile base site contractors, which involved hundreds of millions of dollars. This method of settlement was criticized by the Comptroller General for being a conversion of the contract from a fixed price contract to a cost plus or negotiated form. A cost plus percentage of cost contract is not only illegal but unfair to the government or any owner because it places a premium on waste and even dishonesty in performance. However, conversion, after performance, of all or a part of a job is not objectionable on this basis because the inducement to act unethically is not present. Further, the fee aspect can be controlled and regulated according to the particular circumstance.

There is no doubt but that the total cost basis of settlement does tend to convert the contract to a cost-type, and the Comptroller General's criticism is fiscally sound in so far as it is directed to programs such as the Atlas and Titan missile bases where the government knew, or should have known, in advance of awarding the contracts that it was going to insist on original completion dates although there would be a multiplicity of change orders. The Defense Department's rebuttal is that defense requirements and urgency outweigh such considerations. The Comptroller General's suggested solution is that under similar circumstances the contracts should be awarded as negotiated contracts-thus compelling contractors to keep adequate cost records for that type of work. However, the fact that the total cost method of settlement tends to convert the type of contract is insufficient reason for the government to negotiate every contract where there is a possibility that hindsight will show that a cost-type contract may have been less expensive. There can be no doubt but that, in the long run, competitively bid, fixed-sum contracting is the

\footnotetext{
${ }^{48}$ U.S Comptroller General, Report to Congress, Review of the Administration of Construction of Certain Launch Facilities for the Atlas and Titan Intercontinentat Ballistic Missiles at Selected Air Forge Bases (1963).
} 
most economical method of contracting. In most cases involving acceleration the contract has been properly awarded as a fixed-price contract. Subsequently, due to circumstances which could not have been foreseen, or perhaps because the government reasonably believed the contractor to be behind schedule, an acceleration directive was issued. In this type of acceleration situation, the only fair and just method of compensating the contractor is by the total cost method of equitable adjustment. Obviously, this method should be applied only for the period of time during which the contractor was actually accelerated, unless there are independent reasons for applying total cost to the entire contract and as otherwise limited below, subject to such factors as contractor-caused inefficiencies. This method is the only fair way of compensating the contractor due to the factors pointed out in the I. W. Bateson and Tenney cases, ${ }^{40}$ which evidence the impossibility of contractors isolating and hence adequately proving what actual costs were incurred due to disruption of work sequences, occupational saturation and other labor inefficiency factors. But where a contractor can prove that he has been damaged on this account, he is entitled to an equitable adjustment which includes all increased costs which are the direct and proximate costs of compliance with the unjustified acceleration order. As discussed above, impact costs are within this category.

Briefly restated, the total cost or overall basis of settlement is, for the period of acceleration, the difference between the reasonable costs of the work as anticipated and the reasonable costs of performing the actual work as affected by the acceleration directive.

In Ensign-Bickford Company, ${ }^{50}$ the Armed Services Board of Contract Appeals allowed a total cost method of equitable adjustment in an acceleration case. And in Farnsworth and Chambers Company, ${ }^{51}$ the same Board hesitantly allowed the total cost approach, relying on the fact that the case had been considered by the contracting officer on that basis-and since the contracting officer had admitted that the contract price was reasonable and that the additional costs of performance were in fact related to the acceleration changes. However, the Board noted that it ordinarily disallows the total cost approach since the two factors admitted by the contracting officer in that case were not ordinarily present.

The other court and board cases relating to total cost settlements do not bear directly on acceleration situations but do set out ground rules for the allowance of such settlements, into which rules the acceleration situation fits quite neatly.

The following quotation from Oliver-Finnie Company ${ }^{52}$ is of interest, both in showing the hesitancy of the Court of Claims in allowing total cost settlements and the restricted criteria for their allowance:

As we said in F. H. McGraw and Co. v. United States, I3I Court of Claims 50r, $5 \mathrm{Ir}$, the method of proving damages outlined above is by no means satisfactory, because, among

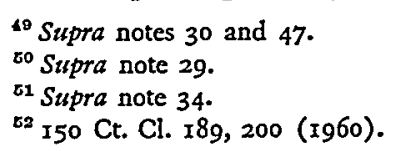


other things, it assumes plaintiff's costs were reasonable and that plaintiff was not responsible for any increase in the costs, and because it assumes plaintiff's bid was accurately computed, which is not always the case, by any means. But, when as here, the contracting officer has not made a finding as to equitable adjustment prior to the suit, where there is nothing in the record to show the plaintiff's bid was too low, and where it has not been proved that plaintiff's costs were unreasonable, or that plaintiff was itself responsible for any increased costs, we have no alternative.... [T] [he nature of most of the excess costs and losses here involved was such that it is impossible to determine with exactitude the damages suffered by the plaintiff. That damages may not be definitely ascertained does not preclude recovery, however, where the fact of damage is clearly established, and a reasonable basis of computation is afforded. ... The Commissioner has found a fair and reasonable determination of such increased costs by the increase of plaintiff's direct labor costs over its original estimate....

In Modern Foods, Inc., ${ }^{53}$ the Armed Services Board of Contract Appeals said, This Board has held that a proper equitable adjustment is the difference between what it would have reasonably cost to perform the work as originally required and what it reasonably cost to perform the work as changed. S. N. Nielsen Co., ASBCA No. I99o (1954). In computing the cost of the work required by a change order, the cost that will be reasonably experienced by the contractor should be used and not necessarily those of the most efficient producer. Dibs Production and Engineering Co., ASBCA No. I438, (1954).

An equal number of cases refuse to allow equitable adjustments on the total cost basis. However, a study of those cases reveals that their disallowance of the method was, without exception, based on the fact that the circumstances presented did not fall within the criteria set forth in prior decisions allowing such settlements. The case of Air-A-Plane Corporation," disallowed a total cost settlement, "absent proof that appellant's bid estimate was sufficiently reliable. . .." The Board said,

Thus, to arrive at an equitable adjustment, the Board needs two figures. First, the actual costs. Second, the costs but for the changes. We have little in the way of proof with respect to the first of these two figures and we have no proof as to the second of these two figures in the instant case.

In $H . R$. Henderson \& Company, and A. and $H .$, Inc., ${ }^{55}$ the Armed Services Board of Contract Appeals affirmed a decision of the Corps of Engineers Board, ${ }^{50}$ which had disallowed an equitable adjustment on the total cost basis and said:

The theory of total cost thus advocated by appellant has been used on occasion but only in extreme cases where the bid figure can be proved to be reasonable, where there are no

"3 ASBCA No. 2090, 57-I BCA 1229. Accord: Great Lakes Dredge \& Dock Co. v. The United States, II6 Ct. Cl. 679 (I950); MacDougald Construction Co. v. The United States, I22 Ct. Cl. 2Io (I952); Roberson Construction Co., ASBCA 6248, 6I-I BCA 2857; Russ Equipment Co., ASBCA 227I, 60-2 BCA 2755; Chris Berg, Inc., Eng. C \& A Bd. No. 522 (I956); Caskel Forge, Inc., ASBCA 7638, r962 BCA 3318; Lake Union Drydock Co., ASBCA No. 3073, 59-I BCA 2229; Tenney Engineering, Inc., ASBCA No. 7352, x962 BCA 3471. See also Western Contracting Corp. v. United States, 144 Ct. Cl. 3 I 8 (1959).

64 ASBCA No. $3842,60-1$ BCA 2547.

${ }^{55}$ ASBCA No. 5146, 60-1 BCA 2662.

${ }^{t 0}$ Eng. BCA No. Ir70 (I958). 
factors other than the change order increasing the costs and where there is no other way to arrive at an equitable adjustment.

In Holly Corporation, ${ }^{57}$ the Armed Services Board of Contract Appeals rejected the total cost method on the grounds that there was no proof that the contract price was reasonable and there was proof of contractor-caused inefficiency. ${ }^{\text {.8 }}$

Both the cases allowing and those disallowing equitable adjustments on a total cost basis seem to require, first of all, proof of damages which, although definite in the sense that they do exist, are indefinite or uncertain in amount. Certainly, most if not all acceleration claims would qualify on that account due to the impossibility of properly isolating impact costs. Once that determination has been made, the courts and boards seem willing to allow a total cost settlement so long as the costs to be compared-i.e., anticipated costs and actual costs-are reasonable.

Some practical difficulty is encountered from those cases which disallow the total cost method of settlement on the ground that the plaintiff or appellant has failed to prove that the anticipated costs of doing the work-i.e., his bid costs-were reasonable. In as much as the government by its procurement regulation ${ }^{50}$ reserves the right to reject a bid where it is found that the bidder is not responsible or the bid price is unreasonable and disproportionate to the government estimate, it should be presumed that where the contract is awarded the government is bound to accept the reasonableness of the price for performing the work. This suggested presumption could not apply where the government, before awarding the contract, suggests to the contractor that its bid may be mistaken and requests reconfirmation of the estimated amount. In some instances, the contractor will reconfirm his bid, although it is entirely possible he has not considered certain significant cost factors. Where the government can show that it did in fact suspect the contractor's bid from its inception, but the contractor nonetheless insisted upon the bid price, we believe that the presumption of reasonableness of the bid would be rebutted. However, in the usual case, the presumption should stand-especially where the contractor has a record of consistent, profitable performance on government contracts. Obviously, the contractor's bid will be found to be lower than the other responsible bids, or he could not have been awarded the contract. The government can make available a cost breakdown showing the contractor's bid, the estimates for other contractors bidding on the work, and the government estimate. More times than not, this analysis will show that the contractor's bid was within a reasonable tolerance of other serious bidders and the government estimate.

In at least one case, Great Lakes Dredge and Dock Co. v. United States, ${ }^{00}$ the

${ }^{67}$ ASBCA No. 3626, 60-2 BCA 2685.

${ }^{68}$ Other cases disallowing total cost settlements on similar grounds are: F. H. McGraw \& Co. v. United States, I3I Ct. Cl. 50I, 5 II (1955); Robertson Electric Co., ASBCA No. 7415, I962 BCA 3468; Plane-Tronics, Inc., ASBCA No. 7202 et al., r962 BCA 3356; Power Equipment Corp., ASBCA 5904, 1964 BCA.

${ }^{50}$ Armed Services Procurement Regulation (ASPR) $\$ 2-404,32$ C.F.R. $\$ 2.404$ (x963); Federal Procurement Regulation (FPR) \& I-2.404.2, 4 I C.F.R. \$ I.2.404-2 (196I).

${ }^{60}$ II6 Ct. Cl. 679 (1950). 
Court of Claims actually averaged all of the other contractors' bids with the government's estimate in an effort to determine what would be a reasonable price for doing the original work. It is submitted that this is not the proper solution of the problem in most cases. This averaging method was not improper in Great Lakes in as much as the contractor in that case admitted making substantial mistakes in the preparation of his bid. However, when no question of mistake is present, a contractor is severely prejudiced by the averaging method, since it penalizes him for submitting a favorable bid to the government, which can only award a contract to the lowest responsible bidder and which has taken full advantage of that low bid up to the time it directed the contractor to accelerate. Except in extraordinary circumstances, such as an admitted mistake in bid, or where the government has at the outset questioned the reliability of the plaintiff's bid, or where the government can show in some other affirmative manner that the bid was materially in error, there should be a presumption that the contractor's bid is a reasonable amount for doing the original work. In cases where the government can affirmatively prove that the contractor's bid estimate was inadequate, the court or board should average all of the bids, other than the contractor's, but including the government's estimate, to determine a basis for the total cost settlement.

The other amount required in a total cost settlement is the actual cost of performing the work as affected by the acceleration directive. These costs can easily be compiled and verified by contractor and/or government audit. In the Atlas and Titan ballistic missile contracts, as reported by the Comptroller General, ${ }^{61}$ the government chose this method to verify contractor costs for the purpose of negotiating total cost settlements. Any arguable items of cost can easily be isolated by audit and where clearly unallowable, or questionable, may be excluded or made the subject of negotiation.

The primary problems connected with the actual cost of performing the work are those raised in the quoted portion of the $J . W$. Bateson case ${ }^{62}$ - to wit: first, that the contractor could necessarily expect some inefficiency from its employees; second, that the contractor anticipated some overtime work; and third, that the contractor incurred some of the inefficiencies claimed due to its own fault or negligence. As to the first two items, the contractor has already been penalized in the sense that he had to increase the amount of his bid to compensate him for anticipated inefficiencies and overtime work. Therefore, unless the government affirmatively rebuts the presumption suggested above, the contractor should not be further penalized on either of these counts. The third factor, if it exists, certainly entitles the government to an offset from the total cost" settlement. In all probability, an inefficient or incompetent contractor will not be unjustifiably accelerated, but in the event he is, the government is entitled to a credit for any contractorcaused inefficiency or incompetency. However, contracting officers, the contract

o1 U.S. Comptroller General Report to Congress, op. cit. supra note 48.

os Supra note 30 . 
boards, and the courts should not expect contractors to volunteer their own inefficiencies. It is incumbent upon the contractor to prove that he was unjustifiably accelerated and that the acceleration directive caused such increased costs as premium time and the consequent, but not consequential, impact inefficiencies. If he proves these items, and the reasonableness of the bid is established, he is entitled to his equitable adjustment on the total cost theory, in the absence of any contrary proof by the government to the effect that his company created some or all of the inefficiencies.

In this regard, two additional factors must be noted. Some additional inefficiency will be created directly by the acceleration which should not be imputed to the contractor, such as the inefficiency of field supervision due to working the longer hours, and so on. Secondly, as stated in Modern Foods, Inc.: "I3 "In computing the cost of the work required by a change order, the costs that will be reasonably experienced by the contractor should be used and not necessarily those of the most efficient producer." Or as stated in Ensign-Bickford Company, ${ }^{64}$ after citing the quotation in Modern Foods: "We have selected the above case for quotation because of the reference in the second sentence to the costs reasonably to be experienced by the contractor as opposed to the costs that were, or might have been, experienced by someone else." We believe that the Court of Claims, in the Oliver-Finnie Company case $^{65}$ intended to put the burden of proving these contractor-caused inefficiencies on the government when they stated: "Where it has not been proved that plaintiff's costs were unreasonable, or that plaintiff was itself responsible for any increased costs, we have no alternative [but to allow the total cost method of settlement]."

\section{VI}

\section{SUMMARY}

Where, under a government contract, the contracting officer fails to properly adjust a contractor's performance schedule for excusable delays, as provided in General Provision Five, and either directs the contractor to accelerate or expedite its performance by adding additional shifts, increasing construction plant and equipment, or working weekends or holidays, or insists upon compliance with the original completion date, the contractor is entitled to an equitable adjustment under the changes article of its contract compensating it for any increased costs attributable to the unjustified acceleration directive. The contractor is entitled to recover not only the premium time paid to its employees and the increased costs of materials, transportation, and so forth, arising out of the compressed performance, but also he is entitled to recover the increased costs incurred due to the disruption of his planned operation sequences, occupational saturation or trade congestion and other labor inefficiencies due to the long hours work, and so on. The so-called Rice doctrine and

\footnotetext{
${ }^{63}$ Supra note 53.

Bu Supra note 29.

${ }^{65}$ Supra note 52 , at 200 .
} 
other cases disallowing as damages those costs that are too consequential or remote from the factors creating them are inapplicable, because such "impact" costs are the direct and proximate result of the acceleration directive. In recognition of the fact that the impact costs cannot be isolated or proven through ordinary or recognized accounting procedures, the contractor's entitlement should be through the so-called total cost basis of settlement-that is, the difference in price beween the reasonable costs for doing the work as bid and the reasonable actual costs of performing the work as affected by the acceleration directive. In the absence of affirmative contrary evidence on behalf of the government, the contractor should be entitled to the presumption that his bid price represents the reasonable cost of doing the work on which the bid was made. In the event of affirmative government evidence rebutting this presumption, the contractor's bid price should be excepted; and the other bidders' estimates and government estimates should be averaged to determine the reasonable cost of doing the work as bid. The actual costs of doing the work can be subjected to audit either by the government or the contractor to determine their reasonableness subject to affirmative proof by the government that it is entitled to set off an amount representing contractor-caused labor inefficiencies over and above the inefficiencies attributable to the acceleration directive.

In United States v. Callahan-Walker Construction Company, ${ }^{66}$ it was held by the United States Supreme Court that the applicable standard for pricing an adjustment under a government contract is to determine from all the facts what is fair and equitable in the particular case. In our opinion, the only fair and equitable basis for pricing an equitable adjustment in most cases involving an unjustified acceleration directive, issued by the government and complied with by the contractor, is the total cost or overall cost basis of settlement.

\footnotetext{
${ }^{00} 3$ I7 U.S. 56 (1942).
} 